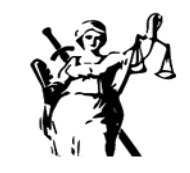

JUSTICIA

ISSN impreso 0124-7441
ISSN digital 2590-4566

\title{
The Necessity in Combating Bioterrorism: An International Experience
}

\section{La necesidad de combatir el bioterrorismo: una experiencia internacional}

\author{
(iD) \\ Petro Melnyk \\ Law of the National University «Odesa Law Academy» \\ melnyk.petro@gmail.com \\ Olena Martovytska \\ Kharkiv National University of Internal Affairs \\ martovickaya.elena@gmail.com
}

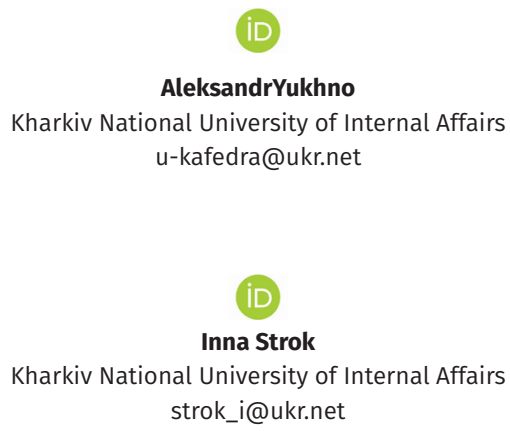

strok_i@ukr.net

Recibido: 22 de junio de 2021 / Aceptado: 21 de agosto de 2021 https://doi.org/10.17081/just.26.40.5208

\begin{abstract}
Objective: The aim of the article is in examining the characteristics of the relevant samples of successful experience of the developed countries in the sphere of combating bioterrorism. Method: The following methods were used by the authors in evaluating the efficiency of the research which involved: historical, analysis as well as bibliographic. Results: The current threats posed by such a phenomenon as bio-terrorism are identified and characterized, as well as successful international examples of its overcoming are analyzed. The level of danger of bio-terrorism has been established, as well as the negative consequences it causes. Cases of real use of biological weapons in different periods of human existence are characterized. It was during this period that various manifestations of bioterrorism around the world became much more active. Emphasis is placed on the fact that combating such a phenomenon as bioterrorism should be based on a comprehensive approach to solving this problem. Among other things, it should be a combination of effective law enforcement, a stable political situation and systematic interaction between the state and the population. Conclusions: The bio-terrorism can be divided into that carried out by criminal organizations, individuals or religious on the one hand, and that carried out by the state on the other. The bioterrorism, together with many of its harmful effects, poses a significant danger to humanity and society. It greatly damages the lives and health of individuals, destroys and destroys nature and the environment, and can create political and economic crises or social upheavals.
\end{abstract}

KEYWORDS: bioterrorism, effective counter-action, crimes against humanity, negative consequences. 


\section{Resumen\}}

Objetivo: El objetivo del artículo es examinar las características de las muestras relevantes de experiencias exitosas de los países desarrollados en el ámbito del combate al bioterrorismo. Método: Los autores utilizaron los siguientes métodos para evaluar la eficiencia de la investigación que involucró: histórico, análisis y bibliográfico. Resultados: Se identifican y caracterizan las amenazas actuales que plantea un fenómeno como el bioterrorismo y se analizan ejemplos internacionales exitosos de su superación. Se ha establecido el nivel de peligro del bioterrorismo, así como las consecuencias negativas que ocasiona. Se caracterizan casos de uso real de armas biológicas en diferentes períodos de la existencia humana. Fue durante este período que varias manifestaciones de bioterrorismo en todo el mundo se volvieron mucho más activas. Se hace hincapié en el hecho de que la lucha contra un fenómeno como el bioterrorismo debe basarse en un enfoque integral para resolver este problema. Entre otras cosas, debe ser una combinación de aplicación efectiva de la ley, una situación política estable e interacción sistemática entre el estado y la población. Conclusiones: El bioterrorismo se puede dividir en el realizado por organizaciones criminales, individuales o religiosas por un lado, y el realizado por el Estado por otro. El bioterrorismo, junto con muchos de sus efectos nocivos, representa un peligro importante para la humanidad y la sociedad. Daña enormemente la vida y la salud de las personas, destruye y destruye la naturaleza y el medio ambiente y puede crear crisis políticas y económicas o trastornos sociales.

PALABRAS Claves: bioterrorismo, contraacción efectiva, crímenes de lesa humanidad, consecuencias negativas.

Como Citar: Melnyk, P., Yukhno, A., MartovytskaO., \& Strok, I. (2021). La necesidad de combatir el bioterrorismo: una experiencia internacional. Justicia, 26(40), 11-18. https://doi.org/10.17081/just.26.40.5208

\section{Introducción}

Scholars tend to argue that the problem aspect of issues related to bio-terrorism in one way or another is quite extensive and multifaceted. The relevance of this topic is also increasing due to the fact that the negative consequences of bio-terrorism can have incredibly severe consequences for the environment. In particular, it is applied to extremely harmful pollution of water bodies and forests which are recognized as one of the largest habitats for many species of plants and animals, i.e. they are important elements of the biosphere. Preservation of environmental safety is defined as a priority in the activities of state authorities.

It should be noted that the peculiarities of modern counter-action to terrorism are that it must function in close mutual cooperation between different countries. Only a joint fight against bio-terrorism can currently have the desired effect. In addition, there is a significant impact that scholars and researchers have on the joint fight of mankind against biological weapons. For example, it is noted that their professional activity in this area is expressed in a qualitative and comprehensive study of all aspects of bioterrorism, the causes of its functioning, as well as the size and nature of its consequences. This, in turn, creates opportunities for humanity to invent effective means to combat such a dangerous social phenomenon as bioterrorism.

The purpose of this article is the characteristics of the relevant samples of successful experience of the developed countries in the sphere of combating bioterrorism. Besides, it is also very important to study the current state of this problem in Ukraine, to conduct assessment of possible risks for domestic society, 
as well as to select those foreign practices on counter-action that would be mostly effective in Ukrainian realities.

\section{Methodology}

In the said article, the authors used a historical method which will help by determining that scientists associate the first mentions of bio-terrorism with historical events that took place during the First World War. Also, using this method, the most famous terrorist acts committed with the help of biological weapons are described.

Using the method of scientific analysis, international documents have been studied, in which the international community has made a call for the refusal to use various types of weapons of mass destruction.

The bibliographic method was useful in the development of scientific literature on the problems of bio-terrorism. The problem established here is not just in having a look at the methods used in combating bio-terrorism, but rather to see whether the established methods are effective in handling issues related to bio-terrorism. One thing is to establish the methods, the other is in ensuring the effective implementation of such methods so as in answering the controversies and doubts surrounding the pandemic of bio-terrorism affecting the world today. There is that aspect of violations as the international community continues to experience adverse effect caused by bio-terrorism causing pain and suffering on humanity. Hopefully, there still exist that gap between the methods used and practical experiences on the field, as issues of gross violations of fundamental human right continue to be questionable and problematic. This continuous violations of Human right by the presence of bio-terrorism constitutes a threat on human existence and security which need to be handle at all level of involvement.

\section{Results and Discussion}

The notion of bio-terrorism has been considered a pandemic constituting a threat on world peace and security. There is that need to combat so as in preventing future manifestation, and this can only be achieved through collaboration of different actors that characterised the international scene. The responsibility of the various actors on the international scene to understand that it is their responsibility in ensuring that this huge pandemic in the capacity of bioterrorism should be combated. The failure in combatting this act will produce adverse effects on humanity. The neglecting this pandemic in the name of bioterrorism will be dangerous as it will constitutes grave violation of fundamental human right which the international community is out to protect. From the findings, it is established that, the ineffective implementation of the various mechanisms on the international scene in combatting bioterrorism will produce devastated effects on human existence. It is therefore at this level that there is the need of the international community to strengthen their cooperation and collaboration so as to ensure a secure and appropriate forum for human habitation.

Based on the recent research accomplished by Western scholars, we should stress that the potential threats and risks of bio-terrorism are extremely high. They pose a significant threat to the lives and health of ordinary citizens, as well as to the stability of governments and political regimes. 
The high danger of biological weapons has been noted in many international Conventions and Treaties that banned or called for the prohibition of those horrific instruments of mass destruction. In particular, we can distinguish among them: the Geneva Protocol, signed by most of the states existing in 1925 (Protocol for the Prohibition). We can confidently say that the Convention has become the first serious document in terms of the of methods of warfare and in the context of the prohibition of certain weapons of mass destruction. Subsequently, this document was repeatedly supplemented by various regulations that extended its effect, including a ban on those weapons of mass destruction that did not even exist at the time of the original document (1925) or were not included there for other reasons.

Over time, being inspired by the originality and relevance of the above Convention, countries began to conclude international Treaties and Conventions similar in content and idea. For example, the Convention on the Prohibition of the Development, Production and Stockpiling of Bacteriological (Biological) and Toxin Weapons and on their Destruction (1972), signed by UN Member States, is noteworthy. In this context, we should refer to the Convention on the Prohibition of the Development, Production, Stockpiling and Use of Chemical Weapons and on their Destruction (1993). This document was quite important at the time of its adoption, as it described and banned almost all types of biological weapons that existed in the late XX century.

In essence, we can conclude that the above international and legal instruments have made a significant contribution to the processes of fighting against bioterrorism, as well as made the world safer. The usefulness of those Conventions is partially based on the fact that they are international, that is they have the same force in many sovereign states.

The history of the use of biological weapons should begin with the events of the First World War. Thus, there is evidence that Kaisers Germany was the first country to actively and widely use biological weapons to destroy its enemies.

According to historical events, biological weapons were once used against the troops and civilians of Great Britain, the United States, France and other European countries of that time. Given the fact that the use of biological weapons had been carried out during hostilities between the states, some scholars opposed calling the actions of German troops as bioterrorism (Sambyal, Sharma, Singh, 2017). On the contrary, given the wide use of biological weapons (mostly poisonous gases of various origins), as well as the huge range of victims, severe and unbearable pain that caused the death of the soldiers of the Entente and other factors, other experts and researchers of those events, as well as experts in the field of modern counter-bioterrorism note that those were a kind of bio-terrorist attacks.

Manifestations of bio-terrorism after the Second World War were no longer committed by the states, but mostly by criminal groups or religious sectarian organizations. The only exceptions were Iraq during Saddam Hussein's rule and Syria during the ongoing civil war. Iraq used chemical and biological weapons in the 1980s and 1990s to exterminate the Kurds by committing total genocide. The Syrian authorities used biological weapons prohibited by international Conventions, not to commit genocide, but to suppress opposition and discontent in society (Tucker, 2000).

In regard to cases of bio-terrorism acts by non-governmental groups, organizations or individuals, it should be noted that they also pose a significant threat to society. It is important to state that according to the findings of a large number of experts in the field of biological weapons, it is much more dangerous, if used indoors or in confined spaces than outdoors.

One of the most daring terrorist attacks committed with biological weapons is the one that took place 
in Chicago, Illinois, USA in 1972. The local police arrested two students of the city college who were planning to poison the water in the city water supply system.

They were going to do this with the help of various dangerous bacteria, including salmonella that contained elements of portable typhoid fever. That situation shocked the society and drew considerable attention to the problems of bioterrorism despite the fact that the perpetrators were detained even before they realized their plans due to the effective actions taken by the police (Petro, Plasse, McNulty, 2003).

Another case of bio-terrorism, which was completed, occurred in 1984 in Oregon. Members of a local Hindu sect carried out a mass (more than 500 victims) food poisoning in the restaurants of the city, where they wanted to win the local elections. Fortunately, fatalities were then avoided, due to the effective actions of American physicians.

However, it is noted that the most famous cases of committing an act of bioterrorism, among all of them, was the spraying of sarin gas in the Tokyo subway by the Japanese terrorist, religious and sectarian organization "Aum-Shinrikyo" in 1993. That act of bioterrorism resulted in the deaths of 12 people, as well as thousands of victims of varying severity. As a result, the group was declared a terrorist in many countries around the world, and the leader and ideological organizer of that terrorist attack was sentenced to death and later killed legally by the Japanese authorities in 2018 (Jansen et al., 2014).

Based on the cases of bioterrorism studied by experts, it was concluded that counter-action to the acts of bioterrorism should focus on the key factors of their spread. In other words, we must protect the targets that are the objects of those types of terrorist acts. If there is the purpose to avoid a terrorist attack similar to the one committed in Milwaukee, Wisconsin in 1993, when poisoning of a local river and associated water bodies served as the city's main source of water supply, led to infection of more than 400,000 people, it is necessary to prevent the defeat of the object of the crime (Janik, Ceremuga, Saluk-Bijak, Bijak, 2019).

In the context of that case, it is necessary to increase (significantly improve) the level of protection of key infrastructure facilities. In particular, it is applied to increasing the level of protection of water bodies that are of strategic importance for the continuous supply of fresh water to a particular city or region. Note that the level of protection of strategic infrastructure facilities in the United States, both federal and local, is recognized as one of the best in the world, despite the fact that most of the bio-terrorist acts described in this article took place in that country. The same is applied to transport networks and places of mass concentration of people (Oliveira et al., 2020). With regard to Ukraine, it should be noted that domestic state structures, as well as society in the whole, we need to learn to effectively resist the threats and dangerous consequences of bioterrorism. Regarding the ways and means of counter-action it is necessary to follow the example of the developed countries, which are able to effectively protect their citizens and their property from various criminal encroachments.

The security of public places should be an unconditional priority in the activities of law enforcement agencies while talking about effective counter-action to bioterrorism in the country. It is also important for civil society to be active, disseminating important information or security rules to various members of the population to protect them.

State authorities and agencies called upon to counteract to bioterrorism need to learn from their more developed and experienced Western allies how to work systematically to counteract to such forms of terrorism. Such work, for example, should consist in a more detailed study and research of biological agents - that is, those harmful biological substances that are actually used by terrorists to commit acts of bioterrorism. To achieve this purpose, it is considered necessary for the state to start allocating 
significant funds for the establishment and implementation of appropriate laboratories and other research institutions, the task of which would be to develop the states ability to search, classify and neutralize such hazardous biological substances.

Experts tend to argue that such purposes are set and successfully achieved by governments of the developed countries. Here with, the ability of a representative of law enforcement agency or any other government agency to find the cause of a terrorist attack, as well as to eliminate its consequences, is the direct indicator of effectiveness and the criterion for the image of the entire state system and the state itself (O'Brien et al., 2021). In addition, high-quality systematic work should be carried out in relation to the specific operational capabilities of law enforcement officers in the field of neutralization of terrorists during their attempt to commit a terrorist act, or their detention at the stage of preparation.

Increasing the state's capacity in this area will also require some financial investment from the government. However, except to the funds themselves, their effective use will be much more important. Foreign researchers and observers point out that Ukraine has lost many opportunities in the past due to low efficiency and lack of competence of state agencies, as well as due to significant corruption. This element of counter-action to bioterrorism raises and exposes another major problem of the domestic state system in general. It is argued that the solution of all other problems and tasks of the state without achieving high efficiency in the use of funds will be more slow (Erenler, Güzel, Baydin, 2018).

Proper control over the efficiency and timeliness of spending funds by state authorities is one of the fundamental components of the functioning of the state in general. It is stated that there should be independent control over the use of funds in the field of combating bioterrorism, as well as in any other sphere of public life. In general, independent and impartial control should be exercised both in relation to the area of spending funds on counter-terrorism and in relation to the level of effectiveness of programs or systems operating in the country.

Leading American researchers emphasize that counter-action to the phenomena and consequences of bioterrorism should be based on close cooperation between law enforcement agencies of the state, as well as its health care authorities. It is pointed out that the fight against bioterrorism in the United States is based on such a principle (Bernard, Bowsher, Gibson-Fall, 2020). We tend to agree with the above statement and to add that it has already received not only further theoretical and scientific dissemination, but also excellent practical implementation. In particular, all other countries, based on the successful practical experience of the United States of America, wishing to improve the quality of their own counter-terrorism, were recommended to create and implement certain high-tech devices. For example, it is related to the introduction of a high-speed computer database into the state health care system, which would contain all the information regarding the components of bioterrorism. These are also dangerous substances of biological origin, which are actually used for committing terrorist acts (Fadzali, 2020). It may also include information on the specific features of the search, detection and neutralization of certain hazardous substances, or their negative consequences. Moreover, such a computer database should have the property of regular rapid updating, because information can be quickly changed at the present time.

The scientific literature emphasizes among other things that it would be much more effective to combine such a system of health care institutions and organizations with some law enforcement computer databases. First of all, it concerns the database of persons who have committed acts of bioterrorism in the past, or are suspected of preparing for them now, or their planning or commission in the near future (Brizee et al.,2019). 
Most researchers and scholars agree that, despite the constant threats posed by so-called "sponsors of terrorism" and various terrorist organizations based on religious hatred or apocalyptic ideology, a clear and powerful functioning of state structures can effectively counteract to them at any level. Assistance of the allies will also be a significant relief for the state in the field of protection to existing threats and challenges, including in the sphere of combating bioterrorism.

\section{Conclusions}

Effective counter-action to bio-terrorism must certainly be of a comprehensive matter, based on it's interaction. Due to the fact that the history of the use of biological weapons for the purpose of committing terrorists acts, or for the purpose of committing genocide, is more than a hundred years old, the means of its use are constantly changing and becoming more complicated. Therefore, society must control the states and their competent authorities to carry out systematic work on improving the quality of the national system for combating bio-terrorism in order it is able to effectively protect itself and its environment from such criminal encroachments. In particular, the authors consider it relevant and urgent to create and implement a computer database containing information on dangerous biological substances (for example, prohibited biological weapons), a law enforcement system of information on former and potential criminals, etc. There should be also information on methods of counteracting a particular type of biological weapon. That is, it means that algorithms for finding and neutralizing the most dangerous substances, as well as their negative consequences must be prescribed.

In general, we note that Ukraine has a lot to learn from the developed Western countries in the field of combating bio-terrorism. For example, it is important to adopt a high level of organization of government agencies' activities in both normal and crisis situations. In addition to the effective functioning of each of the state institutions, it should be stressed that there is the need for their high capacity for the interaction, since researchers argue that a truly effective response to bio-terrorism can be achieved through comprehensive cooperation of all interested parties.

\section{Bibliographic References}

Bernard, R., Bowsher, G. \& Gibson-Fall, F. (2020). Disinformation and Epidemics: Anticipating the Next Phase of Biowarfare. Health Security, 19(1), 3-12.

Brizee, S. et al. (2019). Development of a Biosecurity Checklist for Laboratory Assessment and Monitoring. Applied Biosafety, 24(2). URL: https://www.bureaubiosecurity.nl/en/documenten/paper-onbiosecurity-checklist-development.

Convention on the Prohibition of the Development, Production and Stockpiling of Bacteriological (Biological) and Toxin Weapons and on their Destruction: UN Convention dated from 10 April 1972. URL: https:// zakon.rada.gov.ua/laws/show/995_054\#Text.

Convention on the Prohibition of the Development, Production, Stockpiling and Use of Chemical Weapons and on their Destruction: UN Convention dated from 13 January 1993. URL: https://zakon.rada.gov.ua/ laws/show/995_182\#Text. 
Erenler, A. K., Güzel, M. \& Baydin, A. (2018). How Prepared Are We for Possible Bioterrorist Attacks: An Approach from Emergency Medicine Perspective. The Scientific World Journal. https://doi. $\operatorname{org} / 10.1155 / 2018 / 7849863$

Fadzali, F. (2020). Bioterrorism: Biological Warfare. https://www.researchgate.net/publication/344386783_ Bioterrorism_Biological_Warfare.

Janik, E., Ceremuga, M., Saluk-Bijak, J., \& Bijak, M. (2019). Biological Toxins as the Potential Tools for Bioterrorism. International journal of molecular sciences, 20(5), 1181. https://doi.org/10.3390/ ijms20051181.

Jansen, H. J., Breeveld, F. J., Stijnis1, C. \& Grobusch M. P. (2014). Biological warfare, bioterrorism and biocrime. Clinical Microbiology and Infection, 20, 488-496 DOI: https://doi.org/10.1111/1469-0691.12699.

O'Brien, C., Varty, K. \& Ignaszak, A. (2021). The electrochemical detection of bioterrorism agents: a review of the detection, diagnostics, and implementation of sensors in biosafety programs for Class $\mathrm{A}$ bioweapons. Microsyst Nanoeng, 7(16). https://doi.org/10.1038/s41378-021-00242-5.

Oliveira, M., Mason-Buck, G., Ballard, D., Branicki, W., \& Amorim, A. (2020). Biowarfare, bioterrorism and biocrime: A historical overview on microbial harmful applications. Forensic science international, 314, 110366. https://doi.org/10.1016/j.forsciint.2020.110366.

Petro, J. B., Plasse, Th. R. \& McNulty, J. A. (2003). Biotechnology: impact on biological warfare and biodefense. Biosecurity and Bioterrorism: Biodefense Strategy, Practice, and Science, 1(3), 161-168. http://doi. org/10.1089/153871303769201815

Protocol for the Prohibition of the Use in War of Asphyxiating, Poisonous or Other Gases, and of Bacteriological Methods of Warfare: Geneva, 17 June 1925. International document of the League of Nations. URL: https://zakon.rada.gov.ua/laws/show/995_198\#Text.

Sambyal, S. S., Sharma, P. \& Singh, S. (2017). Bioterrorism and Biological Warfare. International Journal of Science and Research (IJSR). 6(4), 409-412.

Tucker, J. B. (Ed.) (2000). Toxic Terror: Assessing Terrorist Use of Chemical and Biological Weapons. Foreign Affairs. URL: https://www.foreignaffairs.com/reviews/capsule-review/2000-07-01/toxic-terrorassessing-terrorist-use-chemical-and-biological. 